\title{
An Evaluation of Zinc Sulphate Toxicity on Protein, Amino Acid and Transaminase Levels in Freshwater Fish, Channa striata (bloch)
}

\begin{abstract}
Background: Heavy metals may adversely affect the aquatic flora and fauna. Industrial effluents contributing heavy metals on entering into aquatic environment causes biochemical alterations in the fish. Heavy metals are natural components of the aquatic environment, but heavy metal levels have increased due to anthropogenic sources like industrial effluents, agricultural runoff and wastes of mining activities. All the pollutants affect the physicochemical characteristics of the water bodies, sediment and biological components and thus the quality and quantity of fish stocks.

Methods: The present study was to assess the protein, amino acid, aspartate transaminase and alanine transaminase levels in muscle and liver tissues of Channa striata, exposure to sublethal $(15,20$ and $30 \mathrm{mg} / \mathrm{L})$ concentrations of zinc sulphate for the period of 10, 20, 30 and 40 days. Protein levels were estimated by Lowry et al. (1951). Method free amino acids were estimated by Moore and Stein (1954). Method the enzymes ALT and AST were estimated by the strategy of Rietman and Frankel (1957) as described by Bergmeyer (1965).

Result: The fish exposed to zinc sulphate showed a decrease in the protein levels and increase in the amino acid, AST and ALT levels for 10, 20, 30 and 40 days in muscle and liver tissues. The observed mean data were statistically significant at $P<0.05$ of Student's ' $\mathrm{t}$ ' test. The present study indicated alterations in biochemical parameters of Channa striata due to intoxication of zinc sulphate.
\end{abstract}

Key words: Amino acid, ALT, AST, Channa striata, Liver, Muscle, Protein, Sublethal concentration, Zinc sulphate.

\section{INTRODUCTION}

Pollution due to physical, chemical and biological agents exert undesirable influences on human health and environment. In recent times, due to the explosion of human population, urban and industrial growth, more and more freshwater bodies are increasingly polluted with sewage water, as a consequence, there is a heavy damage for fishes. The impact of pollutants upon aquatic and terrestrial animals can be evaluated in terms of toxicity, stimulation, inhibition, destruction and alteration in various metabolic activities (Mahalakshmi, 1997). Fish are widely used to evaluate the health of aquatic ecosystems and physiological alterations serve as biomarkers of environmental pollution (Kock et al., 1996).

Agricultural, industrial and mining effluents containing various organic and inorganic agents, such as solvents, oils, heavy metals, pesticides are discharged into small fresh water bodies without their proper treatment (Pandey et al. 2003). Different kinds of pollutants come from heavy metals, such as cadmium, chromium, copper, iron, zinc, magnesium and mercury.

These metals enter into the aquatic environment through effluents discharged from agriculture runoff, industrial wests mining, dyeing and printing industries, ceramic and pharmaceutical industries (Azmat and Talat, 2006).

Heavy metal pollution in aquatic ecosystem has been recognized as a serious environmental problem. In many
Department of Zoology, University College of Science, Osmania University, Hyderabad-500 007, Telangana, India.

Corresponding Author: P. Pandari Reddy, Department of Zoology, University College of Science, Osmania University, Hyderabad500 007, Telangana, India. Email: pandureddy29@gmail.com

How to cite this article: Reddy, P.P. and Devi, G.S. (2021). An Evaluation of Zinc Sulphate Toxicity on Protein, Amino Acid and Transaminase Levels in Freshwater Fish, Channa striata (bloch). Indian Journal of Animal Research. 55(11): 1342-1346. DOI: 10.18805/IJAR.B-4259.

Submitted: 22-07-2020 Accepted: 24-12-2020 Online: 25-01-2021

cases, heavy metals occur in coastal water bodies at levels, even below their toxic thresholds, however, due to their nondegradable nature, such low concentrations may still pose risk of damage via uptake and subsequent bioaccumulation and biomagnification by organisms. Among environmental pollutants, metals are of particular concern, due to their potential toxic effect and ability to bioaccumulate in aquatic ecosystems, non-biodegradability, propensity of biomagnification in food chain and their effects on the ecological equilibrium of the recipient aquatic body and variety of aquatic organisms (Farombi et al., 2007). Under certain environmental conditions, heavy metals can accumulate to toxic concentrations and cause ecological damage. So, heavy metals acquired through the food chain as a result of 
anthropogenic activities and pollution are potential chemical hazards that can threaten consumers (Guven et al., 1999).

\section{MATERIALS AND METHODS Experimental species}

The fish, Channa striata weighing $27 \pm 1 \mathrm{~g}$ were procured from State Fisheries Culture Tanks. They were transported to the Fish Physiology Lab, Department of Zoology, Osmania University Hyderabad in oxygenated containers and treated with $\mathrm{KMnO}_{4}$ to avoid dermal infection. Fish were fed with commercial feed twice a day at a rate of $2 \%$ of body weight. The $25 \%$ of water in aquaria was replaced regularly. The temperature was maintained at $28 \pm 1^{\circ} \mathrm{C}$, fish were acclimatized under laboratory conditions for 15 days.

\section{Experimental design}

In the present investigation of the long-term test (Chronic toxicity test) carried out during 2016-18. The three sublethal concentrations of $\mathrm{LC}_{50}(120 \mathrm{mg} \mathrm{ZnSO} / \mathrm{L})$ were selected. Three sublethal concentrations of $\mathrm{ZnSO}_{4}$ such as $(15 \mathrm{mg}$, $1 / 8^{\text {th }}$ of $\left.\mathrm{LC}_{50}\right),\left(20 \mathrm{mg}, 1 / 6^{\text {th }}\right.$ of $\left.\mathrm{LC}_{50}\right),\left(30 \mathrm{mg}, 1 / 4^{\text {th }}\right.$ of $\left.\mathrm{LC}_{50}\right)$ were selected and twenty fishes were introduced in each test group. The control and experimental (Zinc Sulphate exposed) fishes were kept under observation up to 40days and various biochemical parameters were estimated at the interval of 10 days (i.e. $10^{\text {th }}$ day, $20^{\text {th }}$ day, $30^{\text {th }}$ day and $40^{\text {th }}$ day). At the end of each experimental duration, five fishes removed for the estimation of biochemical parameters in liver and muscle of fish.

\section{Biochemical analysis}

Protein levels in different tissues were estimated by Lowry et al. (1951). Method free Amino Acids were estimated by Moore and Stein (1954). Method the enzymes ALT and AST were estimated by the strategy of Rietman and Frankel (1957) as described by Bergmeyer (1965). In all the above investigations $10 \%$ homogenate was used for the estimation.

\section{Statistical analysis}

The results were statistically analysed by Student's t-test, all the data was presented as Mean \pm SE. For each experimental treatment, three replicates were taken. For each replicate, under each treatment mean was calculated. The three mean values thus obtained were used to calculate experimental treatment mean and standard errors of mean. $\mathrm{P}$-values were determined using the t-statistics and denoted as NS- Not Significant; ${ }^{*} \mathrm{P}<0.05,{ }^{* \star} \mathrm{P}<0.01,{ }^{* \star *} \mathrm{P}<0.001$.

\section{RESULTS AND DISCUSSION}

After exposing the fish to different sublethal concentrations of zinc sulphate $15 \mathrm{mg} / \mathrm{L}, 20 \mathrm{mg} / \mathrm{L}$ and $30 \mathrm{mg} / \mathrm{L}$ for four different durations $(10,20,30$ and 40 days), protein content, amino acids, AST and ALT levels in muscle and liver of fish, Channa striata, were studied. The alterations in tissue protein, amino acid, AST and ALT levels in different tissues given in Fig 1 to 8 in terms of mean with standard error values and percentage over control.

\section{Protein levels in different tissues}

At the end of experimental durations, the protein levels in different tissues significantly decreased, when compared to control values. The decrease of protein content was more at higher concentration of $\mathrm{ZnSO}_{4}(30 \mathrm{mg} / \mathrm{L})$ and longer duration (40 days). The more protein decrease was observed in liver $(-20.75 \%, \mathrm{P}<0.001)$ compared to muscle $(-15.59 \%$, $\mathrm{P}<0.001$ ) of fish (Fig 1 and 2) at higher sublethal concentration and longer duration of $\mathrm{ZnSO}_{4}$ exposure.

\section{Amino acid levels in different tissues}

In the present study, the amino acid levels in different tissues increased more at higher sublethal concentration of $\mathrm{ZnSO}_{4}$ (30 mg/L) and longer duration (40 days). A significant increase was observed in muscle $(50.92 \%, P<0.001)$ and liver $(51.77 \%, P<0.001)$ of fish at higher concentration and longer duration (Fig 3 and 4).

\section{AST levels in different tissues}

The amount of AST in different tissues significantly increased at the end of experiment durations. The increase of AST levels was more at higher concentration of $\mathrm{ZnSO}_{4}(30 \mathrm{mg} / \mathrm{L})$ and longer exposure duration (40 days). The more increase of AST levels was observed in liver tissue $(20.94 \%, P<0.001)$ compared to muscle $(15.61 \%, P<0.001)$ tissue at higher concentration of $\mathrm{ZnSO}_{4}$ and longer exposure duration (Fig 5 and 6).

\section{ALT levels in different tissues}

In the present investigation, ALT levels significantly

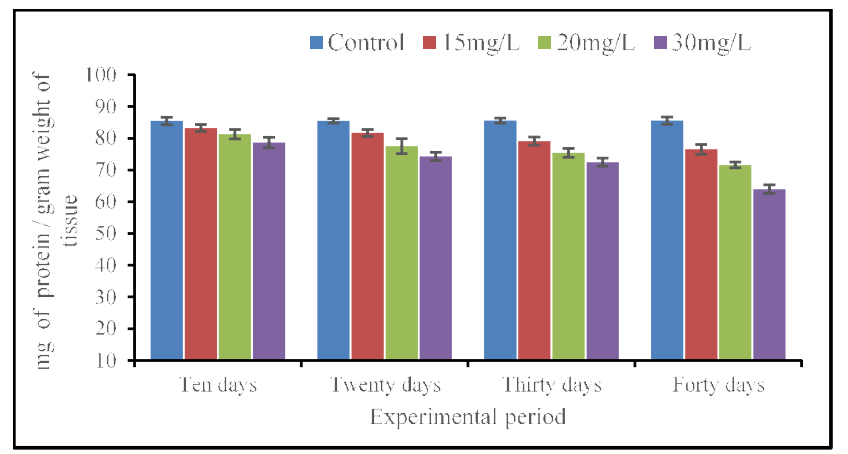

Fig 1: Protein levels in fish muscle after exposure to $\mathrm{ZnSO}_{4}$ (Mean \pm SE).

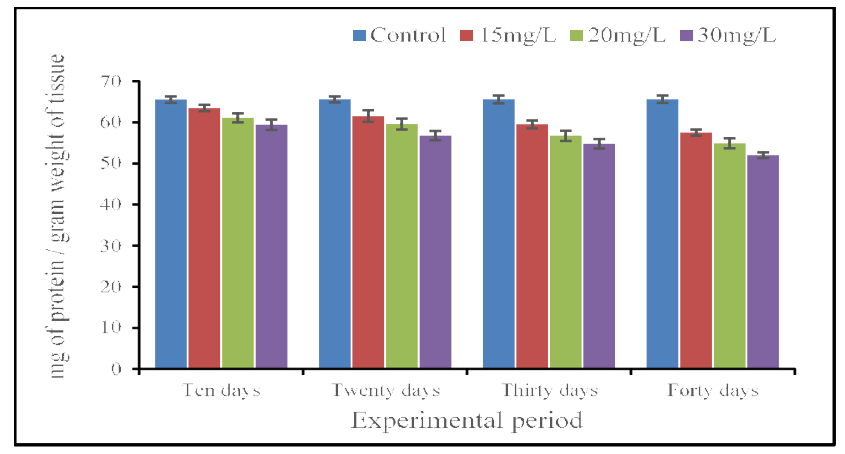

Fig 2: Protein levels in fish liver after exposure to $\mathrm{ZnSO}_{4}$ (Mean \pm SE). 


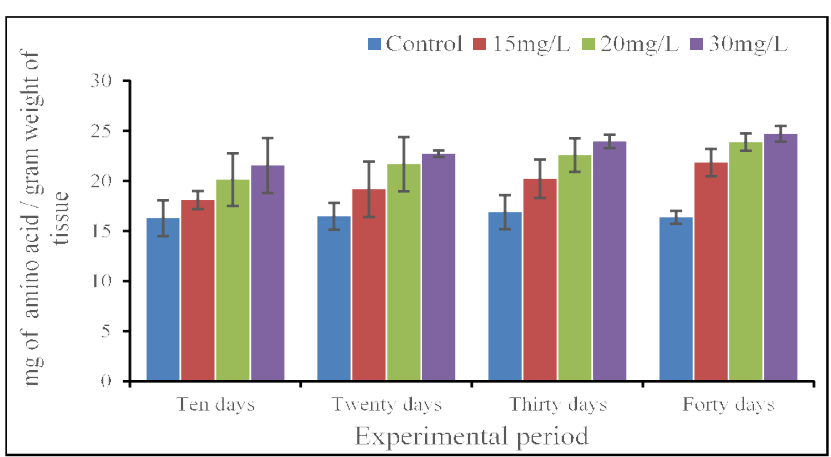

Fig 3: Amino acid levels in fish muscle after exposure to $\mathrm{ZnSO}_{4}$ (Mean \pm SE).

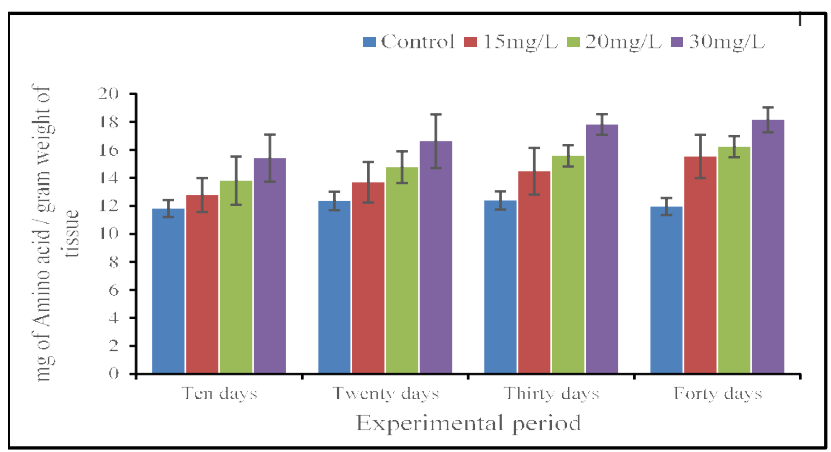

Fig 4: Amino acid levels in fish liver after exposure to $\mathrm{ZnSO}_{4}$ (Mean \pm SE).

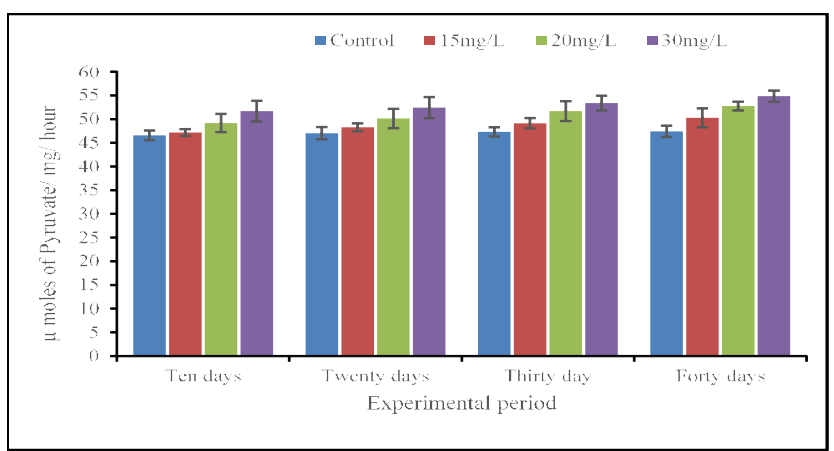

Fig 5: AST levels in fish muscle after exposure to $\mathrm{ZnSO}_{4}$ (Mean \pm SE).



Fig 6: AST levels in fish liver after exposure to $\mathrm{ZnSO}_{4}$ (Mean \pm SE). increased in muscle $(26.55 \%, \mathrm{P}<0.001)$ and liver $(28.65 \%$, $\mathrm{P}<0.001)$ at higher concentration of $\mathrm{ZnSO}_{4}(30 \mathrm{mg} / \mathrm{L})$ and longer exposure duration (40 days). The increase of ALT levels was more at higher concentration and longer duration of $\mathrm{ZnSO}_{4}$ exposure (Fig 7 and 8).

Proteins are the most fundamental and abundant biochemical constituents present in fishes. Proteins are involved in major physiological events and therefore, the assessment of the protein content can be considered as a diagnostic tool to determine the physiological phases of organism. In the present study, muscle and liver protein levels were found decreased under sublethal exposure of $\mathrm{ZnSO}_{4}$. The more decrease was observed in muscle (25.29\%, $\mathrm{P}<0.001)$ compared to liver $(-20.75 \%, P<0.001)$ of fish. The decreased protein levels in the present investigation may be due to the excessive proteolysis to overcome the metabolic stress. The protein contents decrease may be due to breakdown of proteins in the fabrication of little amount of energy for organism (Tulasi and Jayantharao, 2013). Similarly reported that the decreasing trend of protein and increasing levels of amino acid in brain and muscle of Oreochromis mossambicus was exposed to sublethal concentrations of chromium (Senthil Elango and Muthulingam, 2014).

Hence the estimation of free amino acid gives an indication about the physiological and health status of animal (Bais and Lokhande, 2012). Amino acids are essential intermediate substances in the process of protein synthesis and its degradation products appear in the form of different nitrogenous compounds (Karra Somaiah et al., 2015). Amino acid and some nitrogenous compounds play an important role during osmatic stress, its increase or decrease in free amino acid content provides useful information during stress condition at the tissue level (Magar and Afsar Shaikh, 2012).

In the present investigation, a significant increase in free amino acid levels in muscle and liver tissues was observed at all exposure durations and under all sub lethal concentrations of $\mathrm{ZnSO}_{4}$. The order of increase in tissues when exposed to sublethal concentrations, was observed as Liver $(51.77 \%, \mathrm{P}<0.001)>$ Muscle $(50.92 \%, \mathrm{P}<0.001)$ of fish compared to control. The increased amino acid levels in the present study may be due to the breakdown of protein for energy and impaired incorporation of amino acids in protein synthesis. Similar results were obtained by Kamaraj and Ramasamy (2018) who have reported that, the protein contents were reduced whereas amino acid contents elevated in gill, liver and kidney of Hypopthalmichths molitrix when exposed to sublethal concentration of cadmium chloride. Decreased protein levels and increased free amino acid levels in liver, brain and kidney of Labeo rohita were observed under nickel chloride toxicity (Moorthikumar and Muthulingam, 2010).

Aspartate aminotransferase (AST) also known as serum glutamic oxaloacetic transaminase (SGOT) is a pyridoxal phosphate (PLP) - dependent transaminase enzyme. The most important physiological function of Aspartate 
aminotransferase (AST) may be maintenance of the NAD $+/ \mathrm{NADH}$ ratio within cells. AST is a critical partner in the malate- aspartate shuttle, which oxidizes $\mathrm{NADH}$ in the cytosol and reduces NAD+ in the mitochondrial matrix to facilitate glycolysis and electron transport (Mc Commis et al., 2015). In the present study, there was a significant increase in AST levels in muscle and liver at all exposure durations and in all sub lethal concentrations of $\mathrm{ZnSO}_{4}$. The order of increase in different tissues when exposed to sub lethal concentrations was observed as Liver (20.94\%, $\mathrm{P}<0.001)>$ Muscle $(15.61 \%, \mathrm{P}<0.001)$ of fish compared to control. In the present investigation, the increased AST levels may be due to the fish liver inflammation, injury and stress. The present study results were similar to that of Adel Shalaby (2000), who has reported that, the changes were produced in liver and muscle of fish, Cyprinus carpio exposed to sub lethal levels of copper, cadmium or zinc alone or a combination of them for 7 to 30 days.

The most important role of Alanine aminotransferase $(A L T)$ is in the alanine -glucose cycle. In muscle, ALT converts pyruvate to the amino acid alanine using an amino group from glutamate. Alanine enters circulation and is taken up by the liver, where ALT in hepatocytes can convert it back to pyruvate which can be used to make glucose. This system is especially important for glucose regulation during stressful conditions such as fasting or vigorous exercise. It has also been suggested that the mitochondrial isoform of ALT is particularly important in gluconeogenesis in some cases (Mc Commis et al., 2015). In the present investigation, there

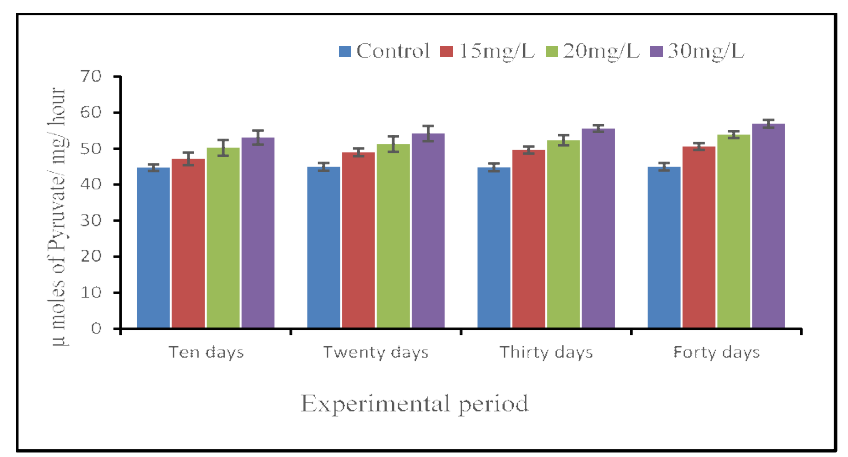

Fig 7: ALT levels in fish muscle after exposure to $\mathrm{ZnSO}_{4}$ (Mean \pm SE).

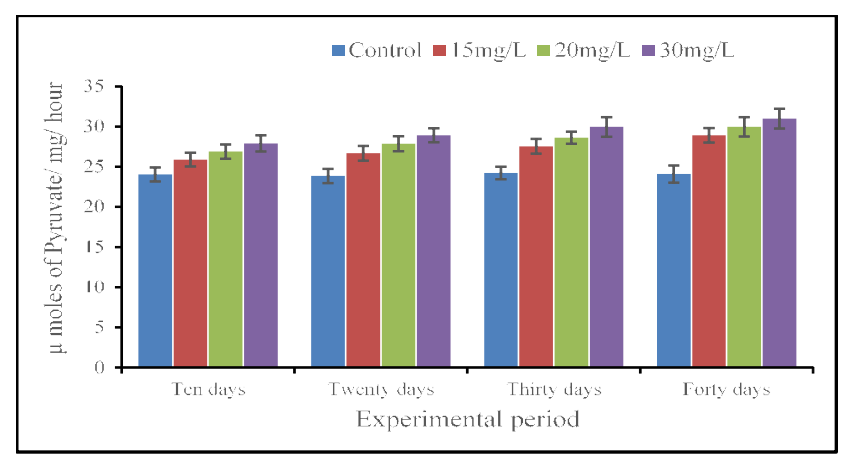

Fig 8: ALT levels in fish liver after exposure to $\mathrm{ZnSO}_{4}$ (Mean \pm SE). was a significant increase in ALT levels in muscle, liver tissues at all durations and in all sub lethal concentrations of $\mathrm{ZnSO}_{4}$. The order of increase in different tissues when exposed to sub lethal concentrations was observed as Liver (28.65\%, $\mathrm{P}<0.001)>$ Muscle $(26.55 \%, \mathrm{P}<0.001)$ of fish compared to control. Increased activity of ALT in the present study may be due to the cellular damage which release the ALT into blood stream and the levels of this enzyme has the potential to indicate hepato-toxicity. Similarly, a significant increase in transaminase (ALT and AST) activity in the fish, Labeo rohita could be possible due to leakage of enzymes across the damaged plasma membranes (Kumari, 2011).

\section{CONCLUSION}

The economically important freshwater fish, Channa striata needs a special attention in view of the present trend to culture these fishes in the freshwater aquatic systems. Such studies are essential to evaluate the toxicity and sub lethal effects of zinc sulphate on the diversified aquatic fauna, occupying different niches of the ecosystem.Since majority of toxic metals are released regularly, through the industrial and public activities, their residues are known to bioaccumulate in the tissues of fish and other species and transfer via food chain to the human body. They pose considerable risk to the health of the people who consume such fish. It is concluded that the utilization of $\mathrm{ZnSO}_{4}$ should be minimized and there is need to create awareness among the people about the toxicity of $\mathrm{ZnSO}_{4}$.

\section{ACKNOWLEDGEMENT}

Authors would like to express great gratitude to Head, Department of Zoology, Osmania University Hyderabad, Telangana State, India for the facilities extended to carry out this research work. The present investigation was financially supported by UGC-BSR-Fellowship.

\section{REFERENCES}

Azmat, R. and Talat, R. (2006). Metal contamination in edible fresh water fishes of Arabian Sea. J. Applied Sci. 6: 1974-1977.

Bais, U.E. and Lokhande, M.V. (2012). Effect of cadium chloride on the biochemical content in different tissues of the fresh water fish, Ophicephalus striatus. International Research Journal of Biological Sciences. 1(7): 55-57.

Bergmeyer, H.U., Bernt, E. and Hess, B. (1965). Lactic Dehydrogenase. In Methods of Enzymatic Analysis. Academic Press, New York, 736-743.

Farombi, E.O, Adelowo, O.A. and Ajimoko, Y.R. (2007). Biomarker of oxidative effect and heavy metal levels of environmental pollution in Clarias gariepinus from Nigeria Ogun River. Int. J. Environ. Res. Public Health. 4: 158-165.

Guven, K., Ozbay Unlu, C., Satar, E. (1999). Acute lethal toxicity and accumulation of copper in [Gammarus pulex (L.) Amphipoda]. Turk. J. Biol. 23: 513-21.

Karra Somaiah and Sunita, K. (2015). Biochemical changes induced by Butachlor, pre-emergent herbicide to sub lethal concentrations in the freshwater fish Labeo rohita (Hamilton). Journal de Afrikana. 2(4): 99Y122. 
Kamaraju, S., Ramasamy, K. (2018). Effect of heavy metal, cadmium chloride on protein and amino acid content changes in freshwater exotic fish, Hypopthalmichthys molitrix. Indo Am. JP. Sci. 05(02): 909-915.

Kock, G., Triendl, M. and Hofer, R. (1996). Seasonal patterns of metal accumulation in Arctic char (Salvelinus alpinus) from an oligotrophic Alpine lake associated with temperature. Can. J. Fish. Aquat. Sci. 53:780-786.

Kumari, K. and Sinha R.C. (2011). Effects of carbaryl and lindane on some biochemical parameters of the blood, liver, muscles, kidney and brain of the frog, Rana tigrina. Bioved. 17: 55-65.

Lowry, O.H. and Rosebrough, N.J. (1951) Protein measurement with folin-phenol reagent. J. Biol. Chem. 193: 265-275.

Magar, R.S. and Afsar Shaikh (2010). Effect of malathion on respiratory responses of fresh water fish, Channa punctatus. Trends in Fisheries Research. 1(3): 1-4.

Mahalakshmi, D. (1997). Effect of Industrial Effluents on Bioaccumulation and Histopathology of a Freshwater Fish, Oreochromis mossambicus, M.Phil, thesis, Annamalai University, India.

Mc Commis, K.S., Chen, Z., Fu, X., Mc Donald, Colca, J.R, Kletzien R.F. (2015). Loss of mitochondrial pyruvate carrier 2 within the liver results in defects in gluconeogenesis and compensation via pyruvate-alanine cycling. Cell Metab. 22: 682-694.

Moore, S. and Stein, W.H. (1954). Procedure for the chromatographic determination of amino acids on four per cent. Crosslinked sulfonated polystyrene resins. Journal of Biological Chemistry. 25(3). 211: 893-906.
Moorthikumar, K. and Muthulingam, M. (2010). Protein metabolism in liver, kidney and brain of Labeo rohita (Hamilton) under heavy metal, nickel chloride stress. International Journal of Current Research. 7: 014-017.

Pandey, S., Parvez, S., Sayeed, I., Haque, R., Bin-Hafeez , B. and Raisuddin, S. (2003). Biomarkers of oxidative stress: A comparative study of river Yamuna fish, Wallago attu (BI. and Schn.). Science of the Total Environment. 309(1-3): 105-115.

Prashanth, M.S. and Neelagund, S.E. (2007). Free cyanide induced biochemical alterations in nitrogen metabolism of the Indian major carp. J. Basic. Clin. Physiol. Pharmacol. 18(4): 277-287.

Reitman, S. and Frankel, S. (1957). A colorimetric method for the estimation of serum glutamic oxaloacetate (SGOT) and glutamic pyruvic transaminases (GPOT). Anim. J. Clin. Path. 28: 56-63.

Senthil Elango, P., Muthulingam, M. (2014). Impact of heavy metal chromium on protein and aminoacid contents in brain and muscle of freshwater fish Oreochromis mossambicus (Peters). International Journal of Current Research. 6(01): 4841-4845.

Tulasi, G. and Jayantha Rao, K. (2013). Effect of chromium on protein metabolism in different tissues of fish, Cyprinus carpio. Res. J. Pharma, Bio. and Chemi. Sci. 4(1): 143 -148. 